\title{
Bathymetric distribution of Mysidacea in fjords of western Norway
}

\author{
Jan Helge Fosså, Torleiv Brattegard \\ Department of Marine Biology, University of Bergen, N-5065 Blomsterdalen, Norway
}

\begin{abstract}
Depth distributions of 20 mysid species sampled between 32 and $1260 \mathrm{~m}$ are presented. A total of 113 sledge samples from 67 stations are evaluated. A change in the mysid fauna correlated to depth was found from the shallowest station and down to about $350 \mathrm{~m}$. Below $350 \mathrm{~m}$, fauna differences between fjords were greater than depth-related variations within fjords. Epibenthic species of Erythrops were found throughout the whole bathymetric range and of Pseudomma from 166 to $1260 \mathrm{~m}$. Shallower than $100 \mathrm{~m}$ Schistomysis ornata and Leptomysis gracilis dominated by number, while deeper Boreomysis megalops and $B$ arctica dominated. Possible effects of the fjord sills on the faunal distribution are discussed. Bathymetric species groups containing all known mysid species from the studied area are proposed: 0 to $50 \mathrm{~m}$ containing 13 species, 30 to $100 \mathrm{~m}$ containing 5 species, 100 to $350 \mathrm{~m}$ containing 5 species, $>250 \mathrm{~m}$ containing 9 species.
\end{abstract}

\section{INTRODUCTION}

In recent years knowledge on the biology and behaviour of hyperbenthic mysids living in Norwegian fjords has increased. Autecological studies have been performed on Boreomysis arctica by Jakupsstovu (1970), Lophogaster typicus by Bjerkestrand (1979) and Praunus flexuosus by Attramadal (1980). Ecological and behavioural studies have been performed on various species (Matthews \& Bakke 1977, Attramadal et al. 1985, Fosså 1985, 1986, Kaartvedt 1985, 1989) and biochemical aspects primarily on $B$. arctica by Brattelid \& Matthews (1978) and Båmstedt (1978, 1981). Mattson (1981) analyzed the importance of mysids as food for fish on prawn trawl grounds. However, much basic knowledge about the mysid species is still not available, including depth distributions of species in the fjords.

There are many observations on the depth occurrences of mysids (e.g. Tattersall \& Tattersall 1951), but few investigations describe continuous distributions, and those which do (e.g. Hargreaves 1985a, b, Murano $1975,1976,1977$ ) are often concentrated on pelagic oceanic species.

Information on the bathymetric distribution of deepliving hyperbenthic species found in Norwegian waters has been gained in other areas (e.g. Mauchline 1982 . 1986, Astthorsson 1984, 1985). However, indirect methods, such as information obtained from stomach content analyses of fish from different depths, have often been used.

The present paper presents results on the bathymetric distribution of species, number of species, and number of individuals of primarily hyperbenthic mysids on level bottoms in west Norwegian fjords. The depth range covered by sampling was 32 to $1260 \mathrm{~m}$. Bathymetric species groups are proposed and an overview is presented of all species known from the area.

\section{STUDY AREA}

Several of the main fjord systems of western Norway, including the deepest threshold fjord known, Sognefjorden (maximum depth $1308 \mathrm{~m}$ ), were studied (Fig. 1). The fjords in the northern area (Stns 1 to 10) have sill depths between 126 and $200 \mathrm{~m}$. Sognefjorden has an outer sill of $164 \mathrm{~m}$ depth while the tributary fjords have no sills. The fjords in the Bergen area have sill depths of $200 \mathrm{~m}$, Hardangerfjorden $150 \mathrm{~m}$, and the inner sills of the fjords of Ryfylke 100 to $120 \mathrm{~m}$.

While watermasses above sill depth in a fjord have free exchange with coastal water outside the fjord, exchange processes in the basin water below sill depth are hampered by the sill. Exchange occurs only when sufficiently dense water appears outside and above the sill. Renewal of the basin water may be partial, or all the old basin water may be flushed out of the fjord. In some 


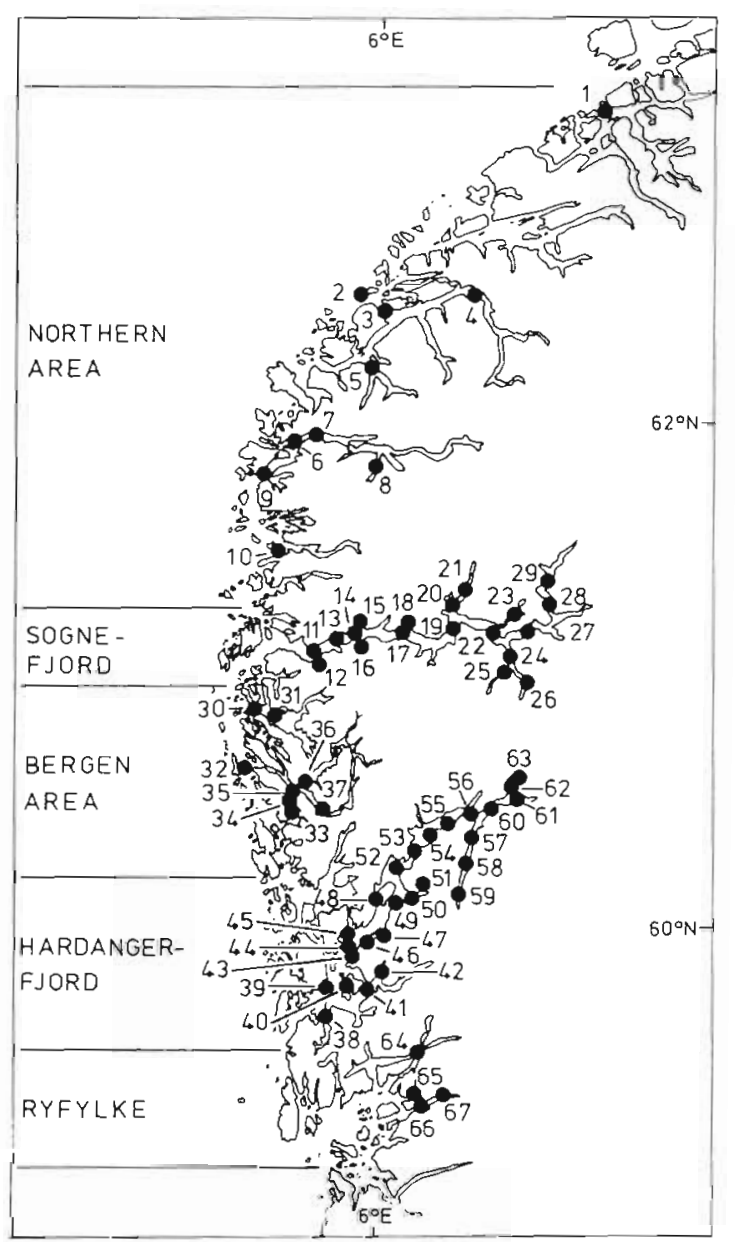

Fig. 1. Sampling stations in fjords of western Norway. (Names indicated for sub-regions are only valid for this investigation)

fjords renewal of the basin water may occur at intervals of several years, for instance about $10 \mathrm{yr}$ in Sognefjorden and Nordfjord (Stns 6 to 8). In some fjords with shallow sill depth and small watermasses a stagnant period may lead to low oxygen levels due to biological respiration and chemical oxygen demand (Aure \& Stigebrandt 1989). It is not known whether any of the stations in the present investigation have had seriously low oxygen levels, i.e. below $2 \mathrm{mg} \mathrm{l}^{-1}\left(=1.4 \mathrm{ml} \mathrm{l}^{-1}\right)$ (Rosenberg 1980). In Sognefjorden, for instance, the lowest oxygen level recorded in the period 1919 to 1970 at 800 to 1200 m was $4.9 \mathrm{ml} \mathrm{l}^{-1}$ (72\% saturation) (Hermansen 1974). In Nordfjord, which was studied during the period 1931 to 1954 , the lowest oxygen content at $400 \mathrm{~m}$ was $2.9 \mathrm{l}^{-1}$ (45\% saturation) (Sælen 1967).

\section{MATERIAL AND METHODS}

Sampling. Samples were collected at 67 different stations in the major fjord systems in western Norway between 1978 and 1985 (Fig. 1, Table 1). Some of the mysids, especially those living shallower than about $300 \mathrm{~m}$, are known to undertake diurnal vertical migrations (Kaartvedt 1985, 1989, Fosså 1986). As a consequence, the number of individuals caught during night and day may differ considerably. To avoid this effect we analyzed only daytime hauls from 0 to $300 \mathrm{~m}$ but both daytime and night-time hauls from deeper than $300 \mathrm{~m}$. A total of 113 samples were used in this work.

Sampling was performed with a slightly modified Rothlisberg and Pearcy epibenthic sledge (Rothlisberg \& Pearcy 1977, Buhl-Jensen 1986, Brattegard \& Fosså unpubl.). The $1 \mathrm{~m}$ wide opening of the $0.5 \mathrm{~mm}$ meshed net samples from 26 to $59 \mathrm{~cm}$ above the sediment when the sledge is in contact with the bottom. When the sledge leaves the bottom the net is closed and precludes pelagic contamination. Most hauls lasted about 20 min at a mean velocity of about 1 knot, which gives a sampled distance of maximally $617 \mathrm{~m}$ or an area of 617 $\mathrm{m}^{2}$. Numbers of individuals in each haul were standardized to a $1000 \mathrm{~m}$ long haul. One sample (1978) was made from RV 'August Brinkmann d.e.', the rest from RV 'Håkon Mosby'.

Numerical methods. The entire bathymetric range covered was divided into 12 depth zones of $100 \mathrm{~m}$, except for the shallowest and deepest zones which were 68 and $160 \mathrm{~m}$, respectively. Pooling of data from different stations into bathymetric zones will obscure between-station variance but depth gradients will be more easily recognized. This effect was, however, desirable in this study. The range of $100 \mathrm{~m}$ was chosen because a finer partitioning would have resulted in too few samples within some of the bathymetric zones while a coarser partitioning would be less sensitive.

Middle depth (Md) calculated for a species was defined as:

$$
M d=\sum_{i=1}^{n} \frac{N_{i} i}{N}
$$

where $N_{1}=$ number of the species in one haul at depth $i_{i} N=$ total number of individuals of the species in all samples: $\mathrm{n}=$ number of samples. The average number of individuals per haul within each bathymetric zone was used when calculating $\mathrm{Md}$.

The sampling intensity was different in the different zones, and rarefaction curves were calculated according to Hurlbert (1971) in order to detect undersampling (Heck et al. 1975, Haila 1983). For this, the number of new species obtained per sample as a function of sample number was plotted.

Affinities between stations and species were andlyzed by means of Detrended Correspondence Analysis (DCA) where detrending by polynomials was used. This procedure is superior to detrending by segments 
Table 1. Samples using RP-sledge from fjords of western Norway between July 1978 and February 1985

\begin{tabular}{|c|c|c|c|c|c|c|}
\hline Stn & $\begin{array}{l}\text { Depth } \\
\text { (m) }\end{array}$ & Fjord & Date & $\begin{array}{c}\text { Time } \\
(\mathrm{h})\end{array}$ & $\begin{array}{l}\text { Latitude } \\
N\end{array}$ & $\begin{array}{c}\text { Longitude } \\
\text { E }\end{array}$ \\
\hline 1 & 326 & Talgsjoen & 9 Jun 81 & $18: 40$ & $63^{\circ} 08.4^{\prime}$ & $07^{\circ} 52.8^{\prime}$ \\
\hline 2 & 258 & Breisund & 10 Jun 81 & $06: 05$ & $62^{\circ} 28.1^{\prime}$ & $05^{\circ} 50.2^{\prime}$ \\
\hline 2 & 258 & Breisund & 12 Aug 81 & $13: 20$ & $62^{\circ} 28.4^{\prime}$ & $05^{\circ} 47.7^{\prime}$ \\
\hline 3 & 450 & Sulafjorden & 19 Mar 81 & $02: 05$ & $62^{\circ} 24.9^{\prime}$ & $06^{\circ} 02.7^{\prime}$ \\
\hline 3 & 450 & Sulafjorden & 19 Mar 81 & $13: 10$ & $62^{\circ} 25.0^{\prime}$ & $06^{\circ} 02.3^{\prime}$ \\
\hline 3 & 446 & Sulafjorden & 10 Jun 81 & $07: 40$ & $62^{\circ} 251^{\prime}$ & $06^{\circ} 01.0^{\prime}$ \\
\hline 3 & 445 & Sulafjorden & 12 Aug 81 & $07: 35$ & $62^{\circ} 253^{\prime}$ & $06^{\circ} 01.6^{\prime}$ \\
\hline 3 & 447 & Sulafjorden & 13 Aug 82 & $17: 00$ & $62^{\circ} 23.5^{\prime}$ & $06^{\circ} 04.2^{\prime}$ \\
\hline 3 & 450 & Sulafjorden & 14 Oct 84 & $13: 15$ & $62^{\circ} 24.2^{\prime}$ & $06^{\circ} 03.3^{\prime}$ \\
\hline 4 & 679 & Storfjorden & 12 Aug 81 & $04: 10$ & $62^{\circ} 26.7^{\prime}$ & $06^{\circ} 50.3^{\prime}$ \\
\hline 5 & 700 & Voldafjorden & 10 Jun 81 & $18: 15$ & $62^{\circ} 10.4^{\prime}$ & $05^{\circ} 57.7^{\prime}$ \\
\hline 5 & 695 & Voldafjorden & 11 Aug 81 & $19: 25$ & $62^{\circ} 10.2^{\prime}$ & $05^{\circ} 59.7^{\prime}$ \\
\hline 5 & 699 & Voldafjorden & 14 Oct 84 & $16: 45$ & $62^{\circ} 10.3^{\prime}$ & $05^{\circ} 58.7^{\prime}$ \\
\hline 6 & 490 & Nordfjorden & 11 Jun 81 & $23: 50$ & $61^{\circ} 54.1^{\prime}$ & $05^{\circ} 19.0^{\prime}$ \\
\hline 7 & 584 & Nordfjorden & 11 Aug 81 & $13: 25$ & $61^{\circ} 55.4^{\prime}$ & $05^{\circ} 26.7^{\prime}$ \\
\hline 7 & 580 & Nordfjorden & 13 Aug 82 & $07: 00$ & $61^{\circ} 55.5^{\prime}$ & $05^{\circ} 28.1^{\prime}$ \\
\hline 7 & 580 & Nordfjorden & 27 Nov 82 & $20: 30$ & $61^{\circ} 55.4^{\prime}$ & $05^{\circ} 253^{\prime}$ \\
\hline 7 & 578 & Nordfjorden & 18 Jun 83 & $17: 15$ & $61^{\circ} 55.4^{\prime}$ & $05^{\circ} 25.3^{\prime}$ \\
\hline 7 & 586 & Nordfjorden & 12 Oct 84 & $06: 20$ & $61^{\circ} 55.4^{\prime}$ & $05^{\circ} 27.0^{\prime}$ \\
\hline 8 & 142 & Hyenfjorden & 12 Oct 84 & $14: 10$ & $61^{\circ} 46.8^{\prime}$ & $05^{\circ} 57.9^{\prime}$ \\
\hline 9 & 382 & Froysjoen & 11 Jun 81 & $05: 10$ & $61^{\circ} 47.3^{\prime}$ & $05^{\circ} 02.3^{\prime}$ \\
\hline 9 & 366 & Froysjoen & 11 Aug 81 & $07: 35$ & $61^{\circ} 47.6^{\prime}$ & $05^{\circ} 02.8^{\prime}$ \\
\hline 10 & 419 & Stavfjorden & 11 Aug 81 & $03: 25$ & $61^{\circ} 28.0^{\prime}$ & $05^{\circ} 07.0^{\prime}$ \\
\hline 10 & 418 & Stavfjorden & 12 Aug 82 & $19: 40$ & $61^{\circ} 28.1^{\prime}$ & $05^{\circ} 07.3^{\prime}$ \\
\hline 10 & 420 & Stavfjorden & 28 Nov 82 & $12: 05$ & $61^{\circ} 28.1^{\prime}$ & $05^{\circ} 07.2^{\prime}$ \\
\hline 11 & 1250 & Sognefjorden & 22 Nov 80 & $03: 15$ & $61^{\circ} 03.0^{\prime}$ & $05^{\circ} 25.0^{\prime}$ \\
\hline 11 & 1250 & Sognefjorden & 13 Mar 81 & $00: 00$ & $61^{\circ} 01.4^{\prime}$ & $05^{\circ} 20.2^{\prime}$ \\
\hline 11 & 1250 & Sognefjorden & 11 Jun 81 & $12: 20$ & $61^{\circ} 02.8^{\prime}$ & $05^{\circ} 25.0^{\prime}$ \\
\hline 11 & 1256 & Sognefjorden & 10 Aug 81 & $21: 35$ & $61^{\circ} 02.8^{\prime}$ & $05^{\circ} 25.0^{\prime}$ \\
\hline 11 & 1252 & Sognefjorden & 24 Aug 82 & $00: 45$ & $62^{\circ} 02.9^{\prime}$ & $05^{\circ} 24.9^{\prime}$ \\
\hline 11 & 1250 & Sognefjorden & 28 Nov 82 & $17: 45$ & $61^{\circ} 03.4^{\prime}$ & $05^{\circ} 22.5^{\prime}$ \\
\hline 11 & 1250 & Sognefjorden & 9 Oct 84 & $00: 20$ & $61^{\circ} 03.1^{\prime}$ & $05^{\circ} 24.5^{\prime}$ \\
\hline 12 & 135 & Risnefjorden & 17 Jan 82 & $08: 50$ & $61^{\circ} 01.6^{\prime}$ & $05^{\circ} 28.7^{\prime}$ \\
\hline 12 & 116 & Risnefjorden & 16 Jun 83 & $12: 40$ & $61^{\circ} 01.5^{\prime}$ & $05^{\circ} 29.1^{\prime}$ \\
\hline 12 & 100 & Risnefjorden & 23 Nov 84 & $14: 00$ & $61^{\circ} 01.3^{\prime}$ & $05^{\circ} 28.6^{\prime}$ \\
\hline 13 & 1257 & Sognefjorden & $24 \operatorname{Mar} 85$ & $07: 25$ & $61^{\circ} 06.6^{\prime}$ & $05^{\circ} 36.0^{\prime}$ \\
\hline 14 & 1260 & Sognefjorden & $17 \operatorname{Jan} 82$ & $00: 25$ & $61^{\circ} 08.6^{\prime}$ & $05^{\circ} 46.1^{\prime}$ \\
\hline 15 & 230 & Vadheimsfjorden & $17 \operatorname{Jan} 82$ & $12: 20$ & $61^{\circ} 11.1^{\prime}$ & $05^{\circ} 48.5^{\prime}$ \\
\hline 15 & 233 & Vadheimsfjorden & 10 Oct 84 & $09: 10$ & $61^{\circ} 11.3^{\prime}$ & $05^{\circ} 48.5^{\prime}$ \\
\hline 16 & 144 & Fuglesetfjorden & $17 \operatorname{Jan} 82$ & $10: 55$ & $61^{\circ} 05.6^{\prime}$ & $05^{\circ} 49.9^{\prime}$ \\
\hline 16 & 147 & Fuglesetfjorden & 23 Nov 84 & $08: 40$ & $61^{\circ} 05.5^{\prime}$ & $05^{\circ} 50.0^{\prime}$ \\
\hline 17 & 1235 & Sognefjorden & $17 \mathrm{Jan} 82$ & $17: 00$ & $61^{\circ} 08.3^{\prime}$ & $06^{\circ} 09.1^{\prime}$ \\
\hline 18 & 40 & Lånefjorden & 22 Nov 84 & $15: 05$ & $61^{\circ} 10.9^{\prime}$ & $06^{\circ} 14.2^{\prime}$ \\
\hline 19 & 1100 & Sognefjorden & 24 Nov 80 & $07: 30$ & $61^{\circ} 10.6^{\prime}$ & $06^{\circ} 33.1^{\prime}$ \\
\hline 19 & 1106 & Sognefjorden & $18 \mathrm{Jan} 82$ & $04: 50$ & $61^{\circ} 09.2^{\prime}$ & $06^{\circ} 35.7^{\prime}$ \\
\hline 19 & 1091 & Sognefjorden & 10 Oct 84 & $12: 45$ & $61^{\circ} 10.2^{\prime}$ & $06^{\circ} 35.9^{\prime}$ \\
\hline 19 & 1040 & Sognefjorden & $18 \mathrm{Jan} 82$ & $00: 05$ & $61^{\circ} 10.4^{\prime}$ & $06^{\circ} 41.4^{\prime}$ \\
\hline 20 & 296 & Fjaerlandsfjorden & 18 Jan 82 & $11: 15$ & $61^{\circ} 13.7^{\prime}$ & $06^{\circ} 34.3^{\prime}$ \\
\hline 21 & 217 & Fjærlandsfjorden & $18 \mathrm{Jan} 82$ & $09: 40$ & $61^{\circ} 18.6^{\prime}$ & $06^{\circ} 40.9^{\prime}$ \\
\hline 22 & 860 & Sognefjorden & $19 \operatorname{Jan} 82$ & $05: 10$ & $61^{\circ} 07.4^{\prime}$ & $06^{\circ} 54.2^{\prime}$ \\
\hline 23 & 260 & Sogndalsfjorden & $18 \mathrm{Jan} 82$ & $14: 10$ & $61^{\circ} 12.5^{\prime}$ & $07^{\circ} 06.0^{\prime}$ \\
\hline 24 & 506 & Aurlandsfjorden & $18 \mathrm{Jan} 82$ & $21: 10$ & $61^{\circ} 00.9^{\prime}$ & $07^{\circ} 02.8^{\prime}$ \\
\hline 24 & 504 & Aurlandsfjorden & 11 Oct 84 & $13: 45$ & $61^{\circ} 00.8^{\prime}$ & $07^{\circ} 02.8^{\prime}$ \\
\hline 25 & 32 & Nærøyfjorden & 11 Oct 84 & $11: 25$ & $60^{\circ} 55.7^{\prime}$ & $06^{\circ} 52.7^{\prime}$ \\
\hline 26 & 410 & Aurlandsfjorden & 18 Jan 82 & $17: 00$ & $60^{\circ} 56.7^{\prime}$ & $07^{\circ} 09.3^{\prime}$ \\
\hline 26 & 412 & Aurlandsfjorden & 11 Oct 84 & $08: 00$ & $60^{\circ} 56.9^{\prime}$ & $07^{\circ} 09.2^{\prime}$ \\
\hline 27 & 935 & Sognefjorden & 19 Jan 82 & $10: 15$ & $61^{\circ} 07.7^{\prime}$ & $07^{\circ} 08.9^{\prime}$ \\
\hline 28 & 648 & Lusterfjorden & $20 \mathrm{Jan} 82$ & $00: 10$ & $61^{\circ} 14.7^{\prime}$ & $07^{\circ} 21.7^{\prime}$ \\
\hline 29 & 373 & Lusterfjorden & 19 Jan 82 & $19: 30$ & $61^{\circ} 20.7^{\prime}$ & $07^{\circ} 22.0^{\prime}$ \\
\hline 30 & 470 & Fensfjorden & 24 Nov 80 & $20: 30$ & $60^{\circ} 50.7^{\prime}$ & $04^{\circ} 52.4^{\prime}$ \\
\hline 30 & 470 & Fensfjorden & 11 Jun 81 & $20: 00$ & $60^{\circ} 50.7^{\prime}$ & $04^{\circ} 52.4^{\prime}$ \\
\hline
\end{tabular}


Table 1 (continued)

\begin{tabular}{|c|c|c|c|c|c|c|}
\hline Stn & $\begin{array}{l}\text { Depth } \\
\text { (m) }\end{array}$ & Fjord & Date & $\begin{array}{l}\text { Time } \\
\text { (h) }\end{array}$ & $\begin{array}{l}\text { Latitude } \\
\qquad N\end{array}$ & $\begin{array}{c}\text { Longitude } \\
\text { E }\end{array}$ \\
\hline 30 & 460 & Fensfjorden & 10 Aug 81 & $18: 15$ & $60^{\circ} 50.7^{\prime}$ & $04^{\circ} 52.4^{\prime}$ \\
\hline 30 & 460 & Fensfjorden & 15 Nov 82 & $16: 35$ & $60^{\circ} 51.5^{\prime}$ & $04^{\circ} 55.5^{\circ}$ \\
\hline 30 & 461 & Fensfjorden & 9 Oct 84 & $15: 35$ & $60^{\circ} 50.9^{\prime}$ & $04^{\circ} 55.2^{\prime}$ \\
\hline 31 & 544 & Fensfjorden & 11 Jun 81 & $22: 00$ & $60^{\circ} 49.8^{\prime}$ & $05^{\circ} 03.2^{\prime}$ \\
\hline 32 & 260 & Hjeltefjorden & 4 Jul 78 & $14: 00$ & $61^{\circ} 350^{\prime}$ & $04^{\circ} 55.0^{\circ}$ \\
\hline 33 & 310 & Byfjorden & 17 Nov 83 & $01: 00$ & $60^{\circ} 25.4^{\prime}$ & $05^{\circ} 16.5^{\prime}$ \\
\hline 34 & 315 & Byfjorden & 16 Nov 83 & $23: 45$ & $60^{\circ} 29.1^{\prime}$ & $05^{\circ} 14.2^{\prime}$ \\
\hline 35 & 522 & Byfjorden & 16 Nov 83 & $19: 25$ & $60^{\circ} 30.7^{\prime}$ & $05^{\circ} 15.6^{\prime}$ \\
\hline 36 & 591 & Osterfjorden & 16 Nov 83 & $14: 45$ & $60^{\circ} 34.3^{\prime}$ & $05^{\circ} 23.7^{\prime}$ \\
\hline 37 & 218 & Sorfjorden & 16 Nov 83 & $12: 35$ & $60^{\circ} 27.4^{\prime}$ & $05^{\circ} 28.6^{\prime}$ \\
\hline 38 & 454 & Ålfjorden & 1. Feb 83 & $19: 20$ & $59^{\circ} 39.5^{\prime}$ & $05^{\circ} 33.1^{\prime}$ \\
\hline 39 & 366 & Klosterfjorden & 1 Feb 83 & $21: 10$ & $59^{\circ} 45.6^{\prime}$ & $05^{\circ} 35.4^{\prime}$ \\
\hline 39 & 365 & Klosterfjorden & 2 Feb 85 & $21: 40$ & $59^{\circ} 45.3^{\prime}$ & $05^{\circ} 34.9^{\prime}$ \\
\hline 39 & 368 & Klosterfjorden & 3 Feb 85 & $09: 25$ & $59^{\circ} 45.3^{\prime}$ & $05^{\circ} 35.3^{\prime}$ \\
\hline 40 & 74 & Eidsvik & 31 Jan 85 & $14: 20$ & $59^{\circ} 48.4^{\prime}$ & $05^{\circ} 41.9^{\prime}$ \\
\hline 41 & 335 & Skăneviksfjorden & 31 Jan 83 & $22: 10$ & $59^{\circ} 48.9^{\prime}$ & $05^{\circ} 53.0^{\prime}$ \\
\hline 42 & 285 & Matrefjorden & 1 Feb 83 & $12: 25$ & $59^{\circ} 48.5^{\prime}$ & $05^{\circ} 58.2^{\prime}$ \\
\hline 42 & 283 & Matrefjorden & 2 Feb 85 & $14: 15$ & $59^{\circ} 48.3^{\prime}$ & $05^{\circ} 58.0^{\prime}$ \\
\hline 43 & 350 & Husnesfjorden & 31 Jan 85 & $21: 15$ & $59^{\circ} 53.1^{\prime}$ & $05^{\circ} 44.9^{\prime}$ \\
\hline 43 & 320 & Husnesfjorden & 1 Feb 85 & $12: 30$ & $59^{\circ} 53.9^{\prime}$ & $05^{\circ} 44.4^{\prime}$ \\
\hline 44 & 511 & Husnesfjorden & 31 Jan 83 & $16: 45$ & $59^{\circ} 54.1^{\prime}$ & $05^{\circ} 43.6^{\prime}$ \\
\hline 44 & 509 & Husnesfjorden & 1 Feb 85 & $13: 30$ & $59^{\circ} 54.4^{\prime}$ & $05^{\circ} 44.4^{\prime}$ \\
\hline 45 & 125 & Onarheimfjorden & 1 Feb 85 & $14: 40$ & $59: 57.1^{\prime}$ & $05^{\circ} 41.4^{\prime}$ \\
\hline 46 & 166 & Onarheimfjorden & $31 \mathrm{Jan} 83$ & $14: 25$ & $59^{\circ} 57.2^{\prime}$ & $05^{\circ} 52.9^{\prime}$ \\
\hline 46 & 164 & Onarheimfjorden & 1 Feb 85 & $10: 10$ & $59^{\circ} 57.2^{\prime}$ & $05^{\circ} 53.1^{\prime}$ \\
\hline 47 & 223 & Onarheimfjorden & 31 Jan 83 & $13: 20$ & $59: 58.2^{\prime}$ & $05^{\circ} 58.7^{\prime}$ \\
\hline 47 & 217 & Onarheimfjorden & 1 Feb 85 & $09: 10$ & $59^{\circ} 58.2^{\prime}$ & $05^{\circ} 59.2^{\prime}$ \\
\hline 48 & 482 & Oynefjorden & 28 Jan 83 & $17: 20$ & $60^{\circ} 07.2^{\prime}$ & $05^{\circ} 55.9^{\prime}$ \\
\hline 49 & 663 & Sildafjorden & 31 Jan 83 & $03: 20$ & $60^{\circ} 06.2^{\prime}$ & $06^{\circ} 05.9^{\prime}$ \\
\hline 49 & 660 & Sildafjorden & 1 Feb 85 & $22: 25$ & $60^{\circ} 06.5^{\prime}$ & $06^{\circ} 06.6^{\prime}$ \\
\hline 49 & 662 & Sildafjorden & 2 Feb 85 & $10: 40$ & $60^{\circ} 06.8^{\prime}$ & $06^{\circ} 06.3^{\prime}$ \\
\hline 50 & 274 & Maurangerfjorden & 2 Feb 85 & $09: 15$ & $60^{\circ} 07.2^{\circ}$ & $06^{\circ} 14.2^{\prime}$ \\
\hline 51 & 197 & Maurangerfjorden & $31 \operatorname{Jan} 83$ & $09: 15$ & $60^{\circ} 08.5^{\prime}$ & $06^{\prime \prime} 16.4^{\prime}$ \\
\hline 52 & 641 & Hissfjorden & $28 \operatorname{Jan} 83$ & $19: 40$ & $60^{\circ} 14.1^{\prime}$ & $06^{\prime} \quad 05.6^{\prime}$ \\
\hline 53 & 835 & Samlatjorden & 31 Jan 83 & $00: 30$ & $60^{\circ} 17.9^{\prime}$ & $06^{\circ} 12.4^{\prime}$ \\
\hline 54 & 854 & Samlafjorden & 30 Jan 83 & $20: 20$ & $6021.6^{\prime}$ & $06^{\circ} 18.6^{\prime}$ \\
\hline 55 & 856 & Samlafjorden & $30 \mathrm{Jan} 83$ & $17: 45$ & $60^{\circ} 25.0^{\prime}$ & $06^{\circ} 26.6^{\prime}$ \\
\hline 56 & 712 & Utnefjorden & 29 Jan 83 & $18: 45$ & $60^{\circ} 24.8^{\prime}$ & $06^{\circ} 41.1^{\prime}$ \\
\hline 57 & 302 & Sørfjorden & $30 \operatorname{Jan} 83$ & $08: 00$ & $60^{\circ} 21.8^{\prime}$ & $06^{\circ} 39.2^{\prime}$ \\
\hline 58 & 386 & Sorfjorden & $30 \mathrm{Jan} 83$ & $12: 40$ & $60^{\circ} 14.7^{\prime}$ & $06^{\circ} 35.6^{\prime}$ \\
\hline 59 & 296 & Sorfjorden & $30 \mathrm{Jan} 83$ & $10: 55$ & $60^{\circ} 10.0^{\prime}$ & $06^{\prime} 33.7^{\prime}$ \\
\hline 60 & 524 & Eidfjorden & 29 Jan 83 & $17: 10$ & $60^{\circ} 27.7^{\prime}$ & $06^{\circ} 46.9^{\prime}$ \\
\hline 61 & 386 & Eidfjorden & 29 Jan 83 & $13: 00$ & $60^{\circ} 29.8^{\prime}$ & $07^{\circ} 00.1^{\prime}$ \\
\hline 62 & 254 & Osafjorden & $29 \operatorname{Jan} 83$ & $09: 55$ & $60^{\circ} 32.3^{\prime}$ & $06^{\circ} 57.1^{\prime}$ \\
\hline 63 & 137 & Osafjorden & $29 \operatorname{Jan} 83$ & $08: 05$ & $60^{\circ} 34.3^{\prime}$ & $07^{\circ} 00.0^{\prime}$ \\
\hline 63 & 131 & Osafjorden & $29 \mathrm{Jan} 83$ & $08: 55$ & $60^{\circ} 34.3^{\prime}$ & $07^{\circ} 00.2^{\prime}$ \\
\hline 64 & 404 & Sandsfjorden & 8 Nov 83 & $09: 30$ & $59^{\circ} 30.0^{\prime}$ & $06^{\circ} 14.5^{\prime}$ \\
\hline 64 & 420 & Sandsfjorden & 8 Nov 83 & $16: 55$ & $59^{\circ} 30.0^{\prime}$ & $06^{\circ} 14.5^{\prime}$ \\
\hline 65 & 315 & Erfjorden & 8 Nov 83 & $19: 45$ & $59^{\circ} 19.0^{\prime}$ & $06^{\circ} 13.0^{\prime}$ \\
\hline 65 & 309 & Erfjorden & 9 Nov 83 & $14: 15$ & $59^{\circ} 19.0^{\prime}$ & $06^{\circ} 13.5^{\prime}$ \\
\hline 66 & 643 & Jøsenfjorden & 9 Nov 83 & $10: 40$ & $59^{\circ} 17.4^{\prime}$ & $06^{\circ} 18.7^{\prime}$ \\
\hline 67 & 110 & Jesenfjorden & 9 Nov 83 & $08: 55$ & $59^{\circ} 19.1^{\prime}$ & $06^{\circ} 26.5^{\circ}$ \\
\hline
\end{tabular}

(ter Braak 1987a). A computer program by ter Braak (1987b) was used. Correspondence analysis (CA) constructs the theoretical variable that best explains the species data. The method does so by choosing the best values for the sites, i.e. values that maximize the dispersion of the species scores. The next axes also max- imize the dispersion but subject to the constraint of being uncorrelated with previous axes. This ensures that new information is expressed on the later axes (ter Braak 1987a). The ordination axes (= eigenvectors) denote a point in a multidimensional space and the eigenvalues are equal to the dispersion of species 
scores. DCA was performed on all 67 stations without pooling into depth intervals.

The related TWINSPAN analysis (Two-way Indicator Species Analysis), which is a dichotomized ordination method based on the partitioning of the first axis of basic CA (Hill 1979, Gauch \& Whittaker 1981) was used to separate (1) species groups and (2) groups of bathymetric zones along ordination axis 1 . Six pseudospecies

Table 2. Number of hauls, mean number of individuals of mysids per haul, and total number of species in the different bathymetric zones in all fjords. $\mathrm{N}$ : number of species having their upper $N(u)$ and lower $N(1)$ limits in the defined bathymetric zones

\begin{tabular}{|rrrrrr|}
\hline $\begin{array}{c}\text { Bathymetric } \\
\text { zone }(\mathrm{m})\end{array}$ & Hauls & $\begin{array}{c}\text { Ind. } \\
\text { haul }\end{array}$ & Species & $\mathrm{N}(\mathrm{u})$ & $\mathrm{N}(\mathrm{l})$ \\
\hline $32-100$ & 3 & 4977 & 9 & 9 & 2 \\
$100-200$ & 12 & 1389 & 11 & 4 & 2 \\
$200-300$ & 16 & 372 & 14 & 5 & 1 \\
$300-400$ & 18 & 279 & 15 & 1 & 1 \\
$400-500$ & 21 & 324 & 13 & & 1 \\
$500-600$ & 13 & 193 & 11 & 2 \\
$600-700$ & 7 & 259 & 9 & 2 \\
$700-800$ & 4 & 133 & 7 & 3 \\
$800-900$ & 4 & 122 & 6 & & 1 \\
$900-1000$ & 1 & 352 & 5 & & 1 \\
$1000-1100$ & 4 & 94 & 4 & & 3 \\
$1100-1260$ & 10 & 201 & 3 & & \\
\hline
\end{tabular}

cut levels were used $(0,2,10,50,100,400)$ (which gives a crude scale of 5 abundance levels used in the analysis; see Hill [1979] for explanation of terms). TWINSPAN first classifies the samples (depth intervals) and then uses this classification to obtain a classification of the species. The result from a (D)CA-ordination is usually plotted in a system of axes and the ordination space partitions are imposed subjectively (drawn on the figure by hand) whereas TWINSPAN partitions are 'objective' and automatic (Gauch 1982).

\section{RESULTS}

\section{Number of species and individuals in depth zones}

The average numbers of individuals per haul were relatively high, 4977 and 1389, in the 2 zones shallower than $200 \mathrm{~m}$ (Tables 2 and 3). Schistomysis ornata and Leptomysis gracilis were the most abundant species, but Lophogaster typicus, Erythrops serrata and Boreomysis megalops were also found in high numbers. Below $200 \mathrm{~m}$ the range of average number of individuals per haul in the depth zones was 94 to 372 . The numbers per haul were slightly higher in the upper part of the bathymetric range.

A total of 20 mysid species were found in the geographic and bathymetric range covered. Boreomysis

Table 3. Depth intervals (m) and species ordered according to TWINSPAN results performed on mean abundance data of species in defined depth intervals. Minimum (Min) and maximum (Max) depth of occurrence, and middle depth (Md) based on data from all stations. (Full species names are given in Table 4)

\begin{tabular}{|c|c|c|c|c|c|c|c|c|c|c|c|c|c|c|c|c|}
\hline & \multirow{3}{*}{ Species } & \multirow[t]{3}{*}{ Min } & \multirow[t]{3}{*}{$\mathrm{Md}$} & \multirow[t]{3}{*}{$\operatorname{Max}$} & \multicolumn{12}{|c|}{ Mean abundance } \\
\hline & & & & & \multicolumn{2}{|c|}{ Group I } & \multicolumn{3}{|c|}{ Group II } & \multicolumn{3}{|c|}{ Group IIl } & \multicolumn{4}{|c|}{ Group IV } \\
\hline & & & & & $\begin{array}{l}32- \\
100\end{array}$ & $\begin{array}{l}100- \\
200\end{array}$ & $\begin{array}{c}200- \\
300\end{array}$ & $\begin{array}{c}300- \\
400\end{array}$ & $\begin{array}{c}400- \\
500\end{array}$ & $\begin{array}{c}500- \\
600\end{array}$ & $\begin{array}{c}600- \\
700\end{array}$ & $\begin{array}{c}700- \\
800\end{array}$ & $\begin{array}{c}800- \\
900\end{array}$ & $\begin{array}{l}900- \\
1000\end{array}$ & $\begin{array}{c}1000- \\
1100\end{array}$ & $\begin{array}{c}1100- \\
1260\end{array}$ \\
\hline & S. norvegica & 40 & 45 & 74 & 13 & & & & & & & & & & & \\
\hline & M. angusta & 32 & 43 & 74 & 4 & & & & & & & & & & & \\
\hline & E. elegans & 32 & 40 & 100 & 20 & 1 & & & & & & & & & & \\
\hline \multirow[t]{4}{*}{1} & S. ornata & 32 & 66 & 350 & 2846 & 8 & 1 & 1 & & & & & & & & \\
\hline & L. graculis & 32 & 89 & 166 & 1256 & 481 & & & & & & & & & & \\
\hline & L. typicus & 32 & 88 & 296 & 489 & 167 & 2 & & & & & & & & & \\
\hline & E. serrata & 40 & 113 & 490 & 326 & 136 & 32 & 23 & 1 & & & & & & & \\
\hline \multirow{2}{*}{2} & B. megalops & 74 & 176 & 663 & 5 & 485 & 159 & 2 & 1 & 1 & 1 & & & & & \\
\hline & M. didelphys & 40 & 194 & 700 & 18 & 22 & 3 & 6 & 2 & 4 & 1 & 1 & & & & \\
\hline \multirow{2}{*}{3} & M. typica & 100 & 175 & 663 & & 82 & 12 & 6 & 1 & & 1 & & & & & \\
\hline & P. obesa & 135 & 287 & 509 & & 3 & 3 & 6 & 1 & 1 & & & & & & \\
\hline \multirow{3}{*}{4} & P. affine & 166 & 345 & 585 & & 1 & 33 & 9 & 27 & 1 & & & & & & \\
\hline & M. insignis & 110 & 487 & 1100 & & 3 & 13 & 10 & 7 & 4 & 4 & 5 & 3 & 3 & 2 & \\
\hline & H. abyssicola & 254 & 438 & 700 & & & 1 & 41 & 9 & 19 & 6 & 1 & & & & \\
\hline \multirow[t]{3}{*}{5} & E. microps & 200 & 481 & 935 & & & 1 & 30 & 18 & 3 & 2 & 1 & 1 & 7 & & \\
\hline & E. abyssorum & 254 & 639 & 856 & & & 23 & 30 & 20 & 21 & 76 & 97 & 56 & & & \\
\hline & A. abbreviata & 254 & 570 & 1260 & & & 77 & 33 & 51 & 18 & 4 & 6 & 4 & 25 & 4 & 36 \\
\hline \multirow[t]{2}{*}{6} & B. arctica & 254 & 774 & 1260 & & & 12 & 60 & 149 & 113 & 164 & 22 & 50 & 231 & 73 & 129 \\
\hline & P. roseum & 320 & 838 & 1260 & & & & 22 & 37 & 8 & & & 8 & 86 & 15 & 36 \\
\hline
\end{tabular}


tridens was only recorded at Stn 1 and is only included in the DCA analysis in the following. The number of species increased from 9 in the shallowest zone to a maximum of 15 in the 300 to $400 \mathrm{~m}$ zone, and decreased to 3 species in the 1100 to $1260 \mathrm{~m}$ zone (Table 2). A steady decrease in species richness with depth of about 2 species per $100 \mathrm{~m}$ was found below $400 \mathrm{~m}$ and no species were added to the mysid fauna below $400 \mathrm{~m}$.

There was a high correlation between number of species caught and the number of hauls within each bathymetric zone ( $\mathrm{r}=0.79, \mathrm{p}=0.005)$. To determine if this was a coincidence or a real interdependence, rarefaction curves were calculated (Fig. 2). Most of the curves level off against an asymptotic value indicating sufficient sampling. The curves for the 600 to $700 \mathrm{~m}$ and 700 to $800 \mathrm{~m}$ bathymetric zones end rather steeply, thus indicating undersampling of species. The curve for the 32 to $100 \mathrm{~m}$ bathymetric zone also levels off. This was rather unexpected because only 3 stations were sampled. However, the theoretical model for the distribution of species among individuals suggests that this zone was sufficiently sampled. Plots of cumulative number of species versus number of samples (not shown) indicated, as the rarefaction-curves did, undersampling between 600 and $800 \mathrm{~m}$, but also for the 32 to $100 \mathrm{~m}$ zone.

\section{Multivariate analyses}

DCA was performed on $\ln (x+1)$ transformed mean abundance data from the 67 stations (Figs. 3 and 4). The eigenvalues for the 4 first axes were $0.756,0.250$, 0.169 and 0.132 , respectively, indicating that the plots in Figs. 3 and 4 depict about $77 \%$ of the variation in the species data. Ordination axis 1 was significantly correlated with depth $(r=-0.68, p<0.001)$ indicating that this axis in essence is describing variance ascribable to depth. Sample scores on axis 1 were plotted against depth (Fig. 5) and clearly showed a steep gradient with depth down to about $350 \mathrm{~m}$. Below $350 \mathrm{~m}$ there was little change related to depth. The ordination plot of samples (Fig. 4) shows that below $350 \mathrm{~m}$ the samples

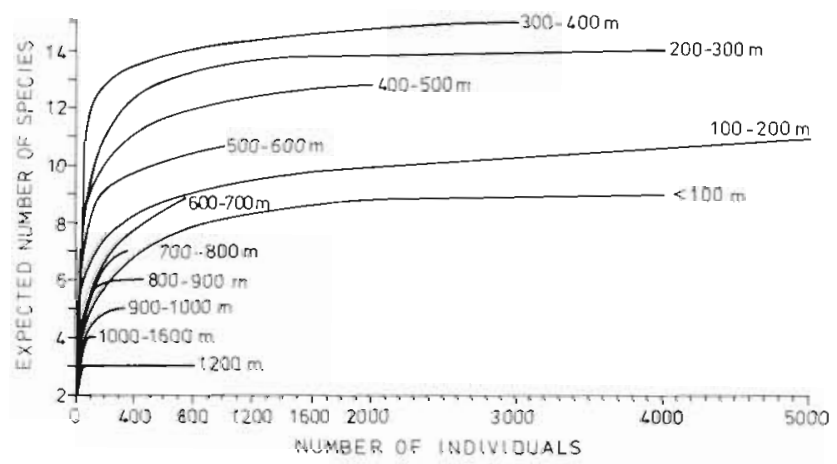

Fig. 2. Rarefaction curves for 12 defined bathymetric zones spread out along axis 2 . This effect was mainly due to Erythrops abyssorum and Pseudomma roseum having the highest and lowest scores on axis 2, respectively (Fig. 3). E. abyssorum was found at deep stations in all areas except in Sognefjorden and had a frequent and wide distribution in Hardangerfjorden. P. roseum was found in every haul deeper than $860 \mathrm{~m}$ in Sognefjorden (corresponds to the cluster of stations down to the left in Fig. 4), and only sparsely at a limited depth range (335 to $510 \mathrm{~m}$ ) in Hardangerfjorden.

TWINSPAN classified the bathymetric zones into 4 groups (Table 3 ). The main division (the first division) occurred at $200 \mathrm{~m}$, and then 2 further divisions occurred at 500 and $800 \mathrm{~m}$, respectively. The species were classified into 6 groups. The first division separated species with main abundance above and below $200 \mathrm{~m}$. Below we summarize the characteristics of the groups.

Species group 1. All species in the group had their only or highest abundance in the 32 to $100 \mathrm{~m}$ zone.

The upper limit of the bathymetric distribution for the 7 species in this group could not be established because no samples were taken above $32 \mathrm{~m}$. The lower

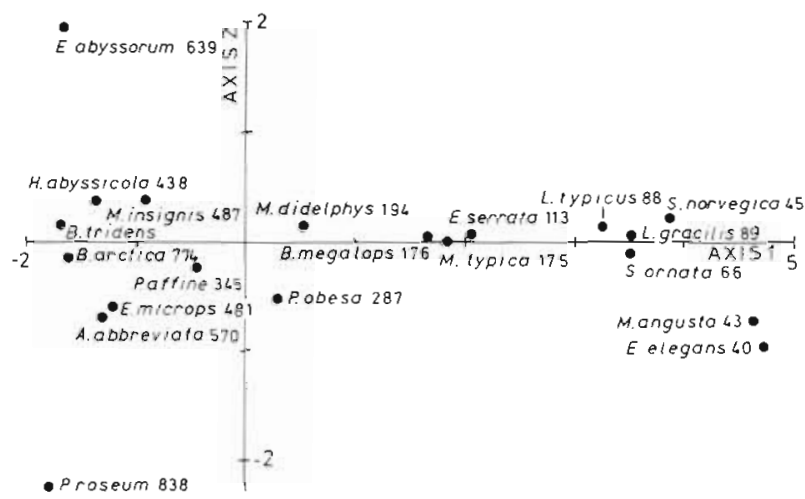

Fig. 3. Correspondence ordination of the 20 mysid species along axes 1 and 2 . The middle depth $(\mathrm{m})$ is given together with the species name

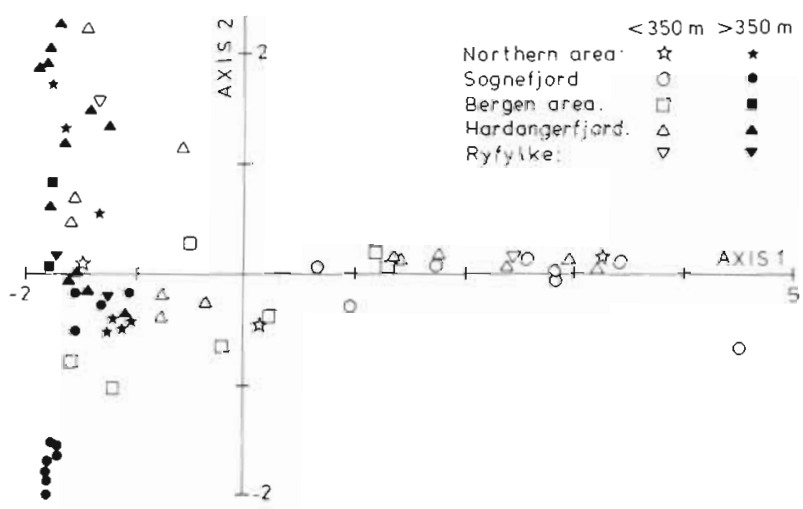

Fig. 4. Correspondence ordination of 67 statıons from fjords in western Norway. Open symbols: stations shallower than 350 $\mathrm{m}$; filled symbols: deeper stations. Five sub-regions (defined in Fig. 1) are separated using different symbols 
limits of the species are well defined because of the comprehensive sampling in the depth range of their deepest distribution (Fig. 6, Table 2).

Siriella norvegica, Mysidopsis angusta and Erythrops elegans had the shallowest distributions, with lower depth limits at 74,74, and $100 \mathrm{~m}$, respectively. The other species in this group (Table 3) were also common between 100 and $200 \mathrm{~m}$ and even if the abundances were low they showed a quite high frequency of occurrence in this zone. E. serrata was recorded down to $490 \mathrm{~m}$.

Species group 2. Mysidopsis didelphys and Boreomysis megalops were both present in the shallowest zone, had their highest abundance in the 100 to $200 \mathrm{~m}$ zone, and showed a wide depth distribution (Fig. 6). M. didelphys was not abundant. In the range 100 to $300 \mathrm{~m}, B$. megalops had a high frequency of occurrence and was the most abundant mysid (Table 3).

Species group 3. Mysidella typica was caught at every station between 100 and $200 \mathrm{~m}$ and had its highest abundance in this range. Parerythrops obesa was both less frequent and less abundant and seemed to prefer deeper stations than $M$. typica. Neither species was recorded in the shallowest zone.

Species group 4. The 2 species Pseudomma affine and Mysideis insignis were recorded in the 100 to $200 \mathrm{~m}$ zone and had their main abundance between 200 and $500 \mathrm{~m}$. P. affine seemed to be concentrated in the 200 to $500 \mathrm{~m}$ range but with 2 peaks. $M$. insignis, although not abundant, showed a remarkably high frequency of occurrence through its whole depth range (Fig. 6).

Species group 5 . The 3 species did not occur shallower than $200 \mathrm{~m}$ and were not caught in the deepest part of Sognefjorden. They had a wide bathymetric distribution: Erythrops microps was distributed from 200 to $935 \mathrm{~m}$. E. abyssorum from 254 to $856 \mathrm{~m}$ and Hemimysis abyssicola from 254 to $700 \mathrm{~m}$ with one peak at 300 to $400 \mathrm{~m}$ and another at 500 to $600 \mathrm{~m}$.

Species group 6. Amblyops abbreviata, Boreomysis arctica and Pseudomma roseum were present at the deepest stations sampled but not recorded shallower than about $250 \mathrm{~m}$. A. abbreviata and B. arctica had the

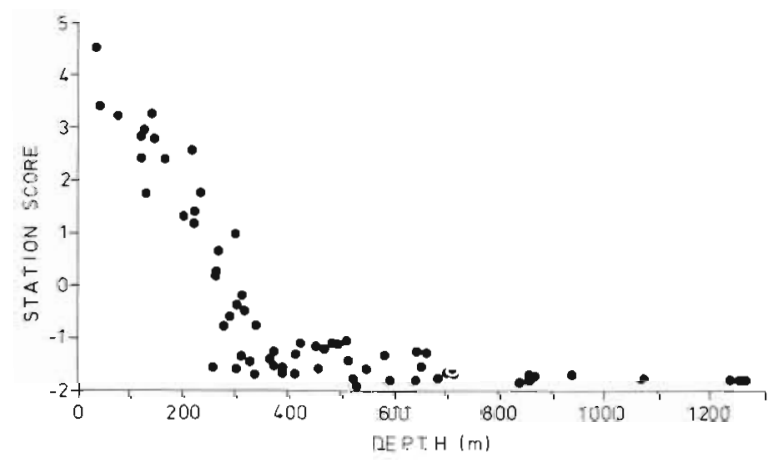

Fig. 5. Station scores on the first axis of the correspondence analysis plotted against the depth of each station same bathymetric range (254 to $1260 \mathrm{~m}$ ), but differed in middle depth (Table 3). A. abbreviata was most abundant in the 200 to $300 \mathrm{~m}$ zone while $B$. arctica was more evenly distributed. The apparent peak between 900 and $1000 \mathrm{~m}$ for $B$. arctica was based on one single haul and could be coincidental. B. arctica was present in every haul deeper than $300 \mathrm{~m}$ and was the most frequent and abundant of all species in this depth range (Fig. 6). P. roseum had a bimadal distribution. In Sognefjorden it was only found at $860 \mathrm{~m}$ and deeper. In the other fjords it was only found between 320 and $544 \mathrm{~m}$.

\section{Congeneric species}

The 4 species of Erythrops were clearly separated in depth distribution (Fig. 6) and along axis 1 of DCA they were separated by 2.8 to $3.7 \mathrm{SD}$ units, except E. microps and $E$. abyssorum which separated along axis 2 by $2.6 \mathrm{SD}$ units (Fig. 3). Pseudomma affine and $P$. roseum also had different depth distributions - the first typified the shallower species. Both species were absent at the deepest stations in Hardangerfjorden and $P$. affine was not recorded in Sognefjorden at all. Boreomysis megalops and $B$. arctica, and Mysidopsis angusta and $M$. didelphys also had different depth distributions with slight overlap.

\section{DISCUSSION}

\section{General distributions of species}

The sampling effort was not evenly distributed in the bathymetric range covered (Table 2). Relatively few samples were taken shallower than $100 \mathrm{~m}$ and between 600 and $1100 \mathrm{~m}$, partly due to lack of suitable level bottoms for towing the RP-sledge. The high correlation between number of samples and species within the bathymetric zones may indicate a causal relationships with the sampling effort. The rarefaction curves (Fig. 2) and sample-species plot (not included) do indicate an undersampling in the 32 to 100,600 to 700 and 700 to 800 $\mathrm{m}$ ranges. The peak in number of species in the 300 to 400 m zone might consequently be questioned. Especially in the 32 to $100 \mathrm{~m}$ range it is likely that some shallow water species were not caught. We are, however, convinced that the number of species shows a general pattern of decrease in species below about $400 \mathrm{~m}$ as no new species were found below $320 \mathrm{~m}$ which lies in the most intensively sampled depth range (Table 2).

The 2 multivariate methods, DCA and TWINSPAN, represent different approaches in analyzing the bathymetric distribution of the mysid fauna. DCA describes a continuous picture and TWINSPAN separates the species into distinct groups. 


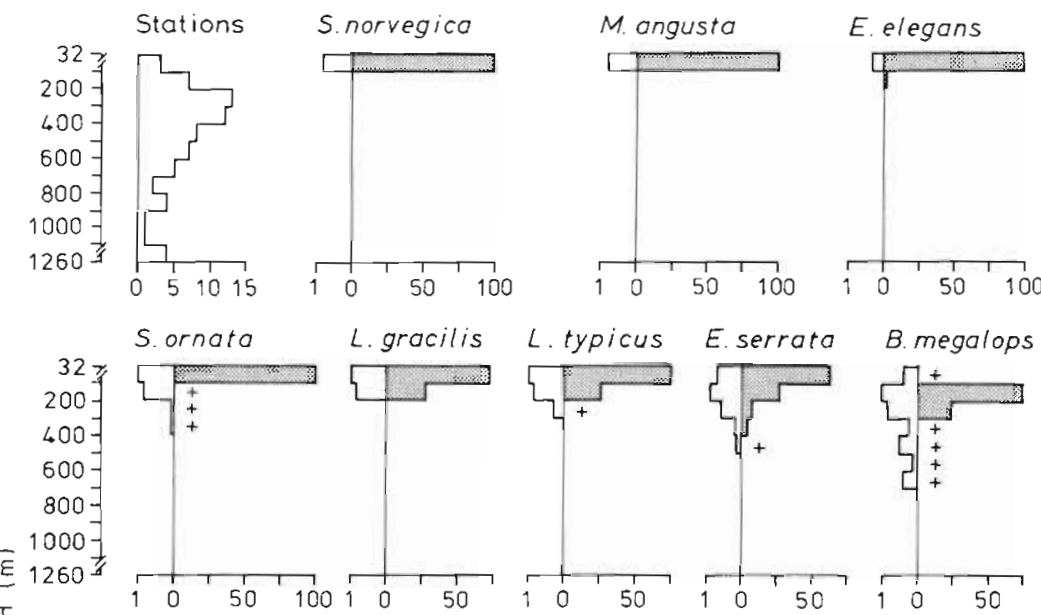

I
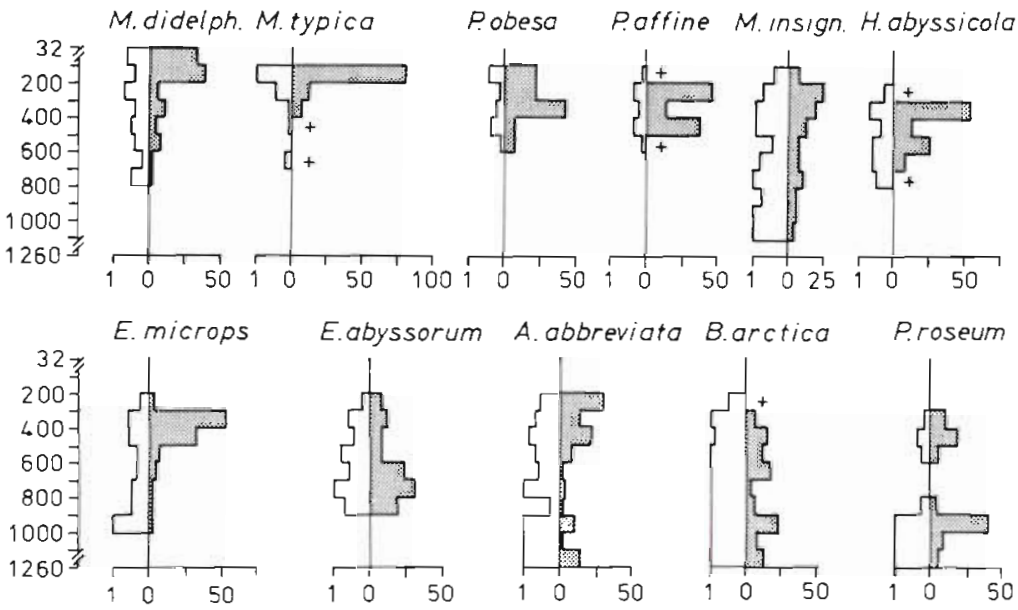

Fig. 6. Numbers of stations in the 12 defined bathymetric zones; frequency of occurrence (white bars) and percentage relative distribution of the species anong the zones (shaded bars). $(+)<2 \%$

The DCA results (Figs. 3 and 4 ) suggested a continuous faunal change related to depth from the shallowest stations to about $350 \mathrm{~m}$. Stations below this depth spread out along ordination axis 2 (Fig. 4). We interpret this as a result of larger faunal differences between fjords than faunal changes due to depth within fjords. TWINSPAN proposed the first division between the depth zones at $200 \mathrm{~m}$ and separated the most abundant shallow-living species from most of the deep-living species (Table 3). It is perhaps the effect of the sills, causing the isolation and stability of the basin water, that is operative around $200 \mathrm{~m}$ where TWINSPAN proposes the first division. Faunal gradients with depth have often been correlated with abiotic factors, for instance temperature, salinity and light intensity (Carney et al 1983). In the fjords both salinity and temperature fluctuate much above the sill depths (maximum about $200 \mathrm{~m}$ ), but are very stable below (e.g. Szelen 1962, Hermansen 1974). We do not know of any factors that could explain the break in the pattern at $350 \mathrm{~m}$ suggested by DCA. Unfortunately, no other datasets exist that present distributional information on animals from fjords and cover a comparable depth range
Erythrops abyssorum and Pseudomma roseum spread the stations along ordination axis 2 (Fig. 3). E. abyssorum was not found in Sognefjorden, while it was widely distributed at appropriate depths south and north of Sognefjorden. Depth per se cannot be the decisive factor as $E$. abyssorum is widely distributed in the North Atlantic and is recorded down to $1100 \mathrm{~m}$ (Tattersall \& Tattersall 1951). In Hardangerfjorden $P$. roseum was restricted to depths between 320 and 511 $m$ in the outer area (Stns 39, 40, 44, 45) while $E$. abyssorum was found throughout the fjord at 254 to $856 \mathrm{~m}$. Neither species was recorded shallower than about $250 \mathrm{~m}$, which is well below sill depth in the fjords studied. Species of Erythrops and Pseudomma studied here are in general epibenthic (Mauchline 1968, Fosså 1986) One possible explanation for the distribution pattern is that, due to substrate preferences, the species are not likely to colonize all types of sedimentary substrates in fjords.

The most widespread and abundant species in the deep fjords is Boreomysis arctica (Table 3, Fig. 6). This species has a wide distribution in the North Atlantic (Tattersall \& Tattersall 1951, Mauchline 1980). In the 
fjords it has both a hyperbenthic and a pelagic element in the populations (Matthews \& Bakke 1977). Its distribution mainly below the sill depths may enhance population maintenance due to reduced advective loss from fjord basins.

The deep fjords also hold stocks of other widely distributed oceanic species, for instance the mesopelagic fishes Maurolicus muelleri and Benthosema glaciale (Gjosaeter 1973, 1981a, b) and the bathypelagic scyphomedusan Periphylla periphylla (Fosshagen 1979). The fjord populations of these species are probably almost isolated from the oceanic populations. The oceanic radiolarian Coeloplegma sp. was present in Jøsenfjorden, Ryfylke, in 1973 to 1975 where it mainly occurred deeper than $275 \mathrm{~m}$. It has not been found in any of the neighbouring fjords (Fosshagen 1979). According to Fosshagen this species is an example of an oceanic species that may have isolated selfsustaining populations in fjord basins. Pelagic copepods endemic to Sognefjorden and Hardangerfjorden are known. They have not been found in other fjords, e.g. in Ryfylke, even after extensive search (Fosshagen 1967, Fosshagen pers. commn). One common trait of the radiolarian and copepod species mentioned above is their distribution well below sill depth.

It seems that the individuality of a fjord is most likely to be found below sill depth. However, in the shallow brackish water too, planktonic species dominating in one fjord may not be recorded in adjacent fjords (Fosshagen 1980, Swanberg \& Bjørklund 1987).

\section{Bathymetric species groups}

Based on results from the DCA and TWINSPAN, and our interpretations, we have defined the bathymetric groups in Table 4. In addition to the species of this study we have presented distributional information on

Table 4. All known mysid species of western Norway grouped into bathymetric groups after their main distribution. In the right column species known to occur in western Norway but not present in our samples are listed

This study

0 to about $50 \mathrm{~m}$

Siriella norvegica G. O. Sars

Mysidopsis angusta G. O. Sars

Erythrops elegans (G. O. Sars)

30 to about $100 \mathrm{~m}$

Schistomysis ornata (G. O. Sars)

Leptomysis gracilis (G. O. Sars)

Lophogaster typicus M. Sars

Erythrops serrata (G. O. Sars)

100 to about $350 \mathrm{~m}$

Boreomysis megalops G. O. Sars

Mysidella typica G. O. Sars

Mysidopsis didelphys (Norman)

Parerythrops obesa (G. O. Sars)

Pseudomma affine $\mathrm{G}$. O. Sars

$>250 \mathrm{~m}$

Boreomysis tridens $\mathrm{G}$. O. Sars

Hemimysis abyssicola G. O. Sars

Mysideis insignis (G. O. Sars)

Erythrops microps (G. O. Sars)

Amblyops abbreviata G. O. Sars

Erythrops abyssorum G. O. Sars

Boreomysis arctica (Kroyer)

Pseudomma roseum G. O. Sars

Other sources

Neomysis integer (Leach)

Praunus flexuosus O. F. Müller

Praunus inermis (Rathke)

Praunus neglectus (G. O. Sars)

Hemimysis lamornae (Couch)

Heteromysis formosa S. I. Smith

Leptomysis lingvura (G. O. Sars)

Michteimysis mixta (Lilljeborg)

Mysidopsis gibbosa G. O. Sars

Schistomysis spiritus (Norman)

Erythrops erythrophthalma (Goes)

Mysidella typhlops G. O. Sars

(a)

(a) Sars (1870-79); (b) Brattegard (1966); (c) Oug (1976); (d) Fosså (1984); (e) own obs. 
all other species of Mysidacea known from western Norway, based on Sars (1870-79), Brattegard (1966). Oug (1976), Fosså (1984) and our own unpublished material.

Group 1 in Table 3 is rather heterogeneous and contains species with quite different bathymetric distributions. Siriella norvegica, Mysidopsis angusta and Erythrops elegans have shallow distributions compared to the others which were common down to $200 \mathrm{~m}$ and some even deeper. For these 3 species this study definitely does not describe a reliable depth distribution because the species are known to be distributed from a few metres depth, and the 2 latter species probably have their main occurrences shallower than the range studied here (Sars 1870-79, Tattersall \& Tattersall 1951, Mauchline 1968, 1970a). For the 4 other species in group 1 (Schistomysis ornata, Leptomysis gracilis, Lophogaster typicus and Erythrops serrata) we have probably sampled the range of their main occurrence (Sars 1870-79, Tattersall \& Tattersall 1951, Mauchline $1968,1969,1970 \mathrm{~b})$. These species were most abundant shallower than $100 \mathrm{~m}$ and frequent down to $200 \mathrm{~m}$. $L$. gracilis was found by Sars (1879) at about $20 \mathrm{~m}$, and the upper limit for the other species may also be shallower than the depths covered by this study. In general, we have too few samples from the 32 to $100 \mathrm{~m}$ depth range. Mauchline (1970b) states that $S$. ornata is associated with E. serrata and L. gracilis in Loch Etive, Scotland In the Norwegian fjords it seems that $L$ gracilis, $L$. typicus and $E$. serrata occur in the same depth range (Fig. 6), while S. ornata seems to prefer more shallow water (Kaartvedt 1989, own obs.). Thus we have chosen to place the 7 species in 2 groups, 0 to 50 and 30 to 100 $\mathrm{m}$. The shallowest interval, 0 to 50 , is mainly outside the depths investigated here. Disregarding this shallowest interval, group 2 and 3 species have much in common and we suggest a single group for Boreomysis megalops, Mysidella typica, Mysidopsis didelphys and Parerythrops obesa together with Pseudomma affine from the next group.

Mysideis insignis was grouped together with Pseudomma affine because of its occurrence in the 100 to $200 \mathrm{~m}$ interval, but we feel that the very extensive depth range really places this species in a group of its own or that it is more naturally placed together with the deeper-living species

Amblyops abbreviata, Boreomysis arctica and Pseudomma roseum have the capability to inhabit the deepest part of Sognefjorden and TWINSPAN separated them from the other deep-living species. However, lacking understanding why this separation exists, we have chosen to put all 7 species in one group together with Mysideis insignis

The species not found by us belong, with 2 exceptions (Erythrops erythrophthalma and Mysidella typh- lops), to the shallowest group. Mich theimysis mixta has the potential of going much deeper (e.g. Salemaa et al 1986) but until now the species, which is not common in the area, has been found down to 30 to $40 \mathrm{~m}$ (Oug 1976). Praunus spp. are abundant in the phytal zone in the fjords except in wave-exposed areas. There is not much information about the other species but most probably they are distributed in the shallow parts of the fjords or, if deeper, in habitats not sampled by the sledge.

Erythrops erythrophthalma was found by Sars (1870) in western and southern Norway at depths between 60 and $110 \mathrm{~m}$. Mysidella typhlops has never been recorded since Sars (1879) found it at about $375 \mathrm{~m}$ depth near Stn 57, and at similar depth between Stns 9 and 10. This species must either inhabit a habitat not sampled by us, or is very rare.

Mauchline (1980) gave a general bathymetric classification of species of mysids. Our 0 to $50 \mathrm{~m}$ corresponds to his 3 groups 'brackish water' ( 0 to $20 \mathrm{~m}$ ), 'littoral' $(0$ to $10 \mathrm{~m}$ ), and 'shallow shelf' (2 to $100 \mathrm{~m}$ ). Our 30 to 100 $\mathrm{m}$ to his 'eurybathic shelf' (2 to $400 \mathrm{~m}$ ), the 100 to $350 \mathrm{~m}$ to his 'deep shelf and upper slope' (100 to $400 \mathrm{~m}$ ) and our deepest $<250 \mathrm{~m}$ to his 'slope' $(200$ to $700 \mathrm{~m})$.

\section{Congeneric species}

TWINSPAN grouped Erythrops elegans and E. serrata, and E. microps and E. abyssorum together, but closer examination of Fig. 6 and Table 3 show that the species have quite different depth distributions. The same is the case for Pseudomma spp. A close examination of Fig. 6 shows that all 6 species of Erythrops and Pseudomma have peaks in abundances in different bathymetric intervals. The scores along the 2 first DCA axes are quite different, and the species are placed at the extremes of both axes, with exception of E. microps and $P$. affine which had similar scores.

Pseudomma roseum and $P$. affine were absent in the deepest zones in Hardangerfjorden even though they occur in much deeper habitats elsewhere (Tattersall \& Tattersall 1951, Mauchline 1986, own obs.). One explanation could be that sediment properties are important. The species of Erythrops and Pseudomma have morphologically similar thoracalic extremities which suggests a similar behaviour at the sediment surface. They may occupy similar niches but at different depths to avoid competition.

Although every depth interval is occupied by typical epibenthic genera as Erythrops and Pseudomma it seems that below $100 \mathrm{~m}$ the most successful species in terms of numbers are Boreomysis megalops and $B$. arctica. They are not as closely associated with and dependent on the substrate as the epibenthic species 
(Fosså 1986) and they are also to some extent pelagic (Matthews \& Bakke 1977. Fosså 1985, Kaartvedt 1989). These species can thus utilize other habitats during their pelagic phase which may give them additional food resources.

Acknowledgements. We are grateful to the captain and crew of RV 'Hakon Mosby' for their cooperation and assistance, to Erik Bonsdorff, Lene Buhl-Jensen, Audun Fosshagen, Stein Kaartvedt, Andreas Mackensen, Jon-Arne Sneli, Jan Sulebak, Jorundur Svavarsson and many others for their participation in the field work, to Stein Kaartvedt and John D. M. Gordon for valuable suggestions for improvements of the manuscript, and to Elin Holm for drawing the figures.

\section{LITERATURE CITED}

Astthorsson, O. S. (1984). The distribution and biology of mysids in Icelandic subarctic waters as demonstrated by analysis of cod stomach contents. Sarsia 69: 107-116

Astthorsson, O. S. (1985). Mysids occurring in the stomachs of cod caught in the Atlantic water south and west of Iceland. Sarsia 70: 173-178

Attramadal, Y G. (1980). Atferden til mysiden Praunus flexuosus (Müller). Thesis, University of Bergen

Attramadal, Y G., Fosså, J. H., Nilsson, H. L. (1985). Changes in behaviour and eye-morphology of Boreomysis megalops G. O. Sars (Crustacea: Mysidacea) following exposure to short periods of artificial and natural daylight. J. exp. mar. Biol. Ecol. 85: 135-148

Aure, J., Stigebrandt, A. (1989). On the influence of topographic factors upon the oxygen consumption rate in sill basins of fjords. Estuar. coast. Shelf Sci. 28: 59-69

Båmstedt, U. (1978). Studies on the deep-water pelagic community of Korsfjorden, western Norway. Seasonal variation in weight and biochemical composition of Chiridius armatus (Copepoda), Boreomysis arctica (Mysıdacea), and Eukrohnia hamata (Chaetognatha) in relation to the1r biology. Sarsia 63: 145-154

Bamstedt, U. (1981). Water and organic content of boreal macrozooplankton and their significance for the energy content. Sarsia 66: 59-66

Bjerkestrand, B. I. (1979). Lophogaster typicus (M. Sars) (Crustacea, Mysidacea) i Fanafjorden. Reproduksjon, vekst og energi-innhold. Thesis, University of Bergen

Brattegard, T (1966). The natural history of the Hardangerfjord. 7. Horizontal distribution of the fauna of rocky shores. Sarsia 22: 1-54

Brattelid, T E., Matthews, J. B. L. (1978). Studies on the deepwater pelagic community of Korsfjorden, western Norway. The dry weight and calorie content of Euchaeta norvegica (Copepoda), Boreomysis arctica (Mysidacea), and Meganyctiphanes norvegica (Euphausiacea). Sarsia 63: 203-211

Buhl-Jensen, L. (1986). The benthic amphipod fauna of the west-Norwegian continental shelf compared with the fauna of five adjacent fjords. Sarsia 71: 193-208

Carney, R. S., Haedrich, R. L., Rowe, G. T (1983). Zonation of fauna in the deep sea. In: Rowe, G. T (ed.) Deep-sea biology. Vol. 8 in the series 'The Sea' John Wiley \& Sons, New York, p. 371-398

Fosså, J. H. (1984). Ressursdeling mellom dyptlevende hyperbenthiske mysider: en nisjeanalyse. Thesis, University of Bergen

Fosså̉, J. H. (1985). Near-bottom vertical zonation during day- time of deep-living hyperbenthic mysids (Crustacea: Mysidacea). Sarsia 70: 297-307

Fosså, J. H. (1986). Aquarium observations on vertical zonation and bottom relationships of some deep-living hyperbenthic mysids (Crustacea: Mysidacea). Ophelia 25. 107-117

Fosshagen, A. (1967). Two new species of calanoid copepods from Norwegian fjords. Sarsia 29: $307-320$

Fosshagen, A. (1979). Dyreplankton i Ryfylkefjordene. Rădgivende utvalg for fjordundersokelser, Oslo

Fosshagen, A. (1980). How the zooplankton community may vary within a single fjord system. In: Freeland, H. J., Farmer, D. M., Levings, C. D. (eds.) Fjord oceanography. Plenum Press, New York, p. 399-405

Gauch, H. G. (1982). Multivariate analysis in community ecology. Cambridge University Press, Cambridge

Gauch, H. G., Whittaker, R. H. (1981). Hierarchical classification of community data. J. Ecol. 69: 537-557

Gjosæter, J. (1973). Age, growth, and mortality of the myctophid fish, Benthosema glaciale (Reinhardt), from western Norway. Sarsia 52: 1-14

Gjosceter, J. (1981a). Growth, production and reproduction of the myctophid fish Benthosema glaciale from Western Norway and adjacent seas. FiskDir Skr Ser. HavUnders. 17: $79-108$

Gjøsæeter, J. (1981b). Life history and ecology of Maurolicus muelleri (Gonostomatidae) in Norwegian waters. FiskDir. Skr. Ser HavUnders. 17: 109-131

Haila, Y (1983). Land birds on northern island: a sampling metaphor for insular colonization. Oikos 41 334-351

Hargreaves, P. M. (1985a). The distribution of Mysidacea in the open ocean and near-bottom over slope regions in the northern North-East Atlantic Ocean during 1979. J. Plankton Res. 7: 241-261

Hargreaves, P. M. (1985b). The vertical distribution of Decapoda, Euphausiacea, and Mysidacea at $42^{\circ} \mathrm{N}, 17^{\circ} \mathrm{W}$ Biol. Oceanogr. 3: 431-464

Heck, K. L., van Belle, G. Simberloff, D. (1975). Explicit calculation of the rarefaction diversity measurement and the determination of sufficient sample size. Ecology 56: $1459-1461$

Hermansen, H. O. (1974). Sognefjordens hydrografi og vannutveksling. Thesis, University of Oslo

Hill, M. O. (1979). TWINSPAN - A FORTRAN program for arranging multivariate data in an ordered two-way table by classification of the individuals and attributes. Cornell University, Ithaca, New York

Hurlbert, S. H. (1971). The nonconcept of species diversity: a critique and alternative parameters. Ecology 52: 577-586

Jakupsstovu, S. H. (1970). Boreomysis arctica (Kroyer 1861) (Crustacea Mysidacea): Arssyklus, vertikalutbredelse, næringsforhold og parasitter i Korsfjorden, Vest-Norge. Thesis, University of Bergen

Kaartvedt, S. (1985). Diel changes in small-scale vertical distribution of hyperbenthic mysids. Sarsia 70:287-295

Kaartvedt, S. (1989). Retention of vertically migrating suprabenthic mysids in fjords. Mar. Ecol. Prog. Ser. 57. $119-128$

Matthews, J. B. L., Bakke, J. L. W. (1977). Ecological studies on the deep-water pelagic community of Korsfjorden (western Norway). The search for a trophic pattern. Helgoländer wiss. Meeresunters. 30: 47-61

Mattson, S. (1981). The food of Galeus melastomus, Gadiculus argenteus thori, Trisopterus esmarkii, Rhinonemus cimbrius, and Glyptocephalus cynoglossus (Pisces) caught during the day with shrimp trawl in a West-Norwegian fjord. Sarsia 66: 109-127 
Mauchline, J. (1968). The biology of Erythrops serrata and E. elegans (Crustacea, Mysidacea). J. mar. biol. Ass. U.K. 48: $455-464$

Mauchline, J. (1969). The biology of Leptomysis gracilis and $L$. lingvura (Crustacea, Mysidacea). J. mar biol. Ass. U.K. 49: 379-389

Mauchline, J. (1970a). The biology of Mysidopsis gibbosa, $M$. didelphys and $M$. angusta (Crustacea, Mysidacea). J. mar. biol. Ass. U.K. 50: 381-396

Mauchline, J. (1970b). The biology of Schistomysis ornata (Crustacea, Mysidacea). J. mar. biol. Ass. U.K. 50: 169-175

Mauchline, J. (1980). The biology of mysids and euphausijds. Adv. mar. Biol. 18: 1-681

Mauchline, J. (1982). The predation of mysids by fish of the Rockall Trough, northeastern Atlantic Ocean. Hydrobiologia 93: 85-99

Mauchline, J. (1986). The biology of the deep-sea species of Mysidacea (Crustacea) of the Rockall Trough. J. mar biol Ass. U.K. 66: 803-824

Murano, M. (1975). Mysidacea from the central and western Pacific II. Genera Hyperamblyops, Teraterythrops and Synerythrops (Tribe Erythropini). Publs Seto mar. biol. Lab. 22: 81-103

Murano, M. (1976). Mysidacea from the central and western Pacific III. Genera Eoerythrops, Holmesiella, Pteromysis, Longithorax and Katerythrops (Tribe Erythropini). Publs Seto mar. biol. Lab. 23: 19-50

Murano, M. (1977). Mysidacea from the central and western Pacific IV Genera Euchaetomera, Euchaetomeropsis, Arachnomysis, Echnomysides, Meterythrops and Nipponerythrops (Tribe Erythropini). Publs Seto mar. biol. Lab. 24: 141-192

Oug, E. (1976). LIndåspollenes hyperfauna. sammensetning, arsvariasjon og de viktigste artenes biologi. Thesis, University of Bergen

This article was presented by Dr J. Mauchline, Oban, United Kingdom
Rosenberg, R. (1980). Effect of oxygen deficiency on benthic macrofauna in fjords. In: Freeland, H. J., Farmer, D. M., Levings, C. D. (eds.) Fjord oceanography. Plenum Press, New York, p. 499-514

Rothlisberg, P. C., Pearcy, W. G. (1977). An epibenthic sampler used to study the ontogeny of vertical migration of Pandalus jordani (Decapoda, Caridea). Fish. Bull. U.S. 74: 994-997

Salemaa, H., Tyystjarvi-Muuronen, K., Aro, E. (1986). Life histories, distribution and abundance of Mysis mixta and Mysis relicta in the northern Baltic Sea. Ophelia 4 (Suppl.): 239-247

Swanberg, N. R., Bjorklund, K. R. (1987). Radiolaria in the plankton of some fjords in western and northern Norway: The distribution of species. Sarsia 72: 231-244

Sars, G. O. (1870-79). Carcinologiske bidrag til Norges fauna. Monographi over de ved Norges kyster forekommende mysider (3 vols). Christiania

Salen, O. H. (1962). The natural history of the Hardangerfjord. 3. The hydrographical observations 1955-1956. Tables of observations and longitudinal sections. Sarsia 6:1-25

Sxlen, O. H. (1967). Some features of the hydrography of Norwegian fjords. In Lauff, G. H. (ed.) Estuaries. Brögger and Christie's Bogtrykkeri. Publs Am. Ass. Advmt Sci., Washington D.C., p. 63-70

Tattersall, W. M., Tattersall, O. S. (1951). The British Mysidacea. Ray Society, London

ter Braak, C. J. F. (1987a). Ordination. In: Jongman, R. H. G. ter Braak, C. J. F, van Tongeren, O. F. R. (eds.) Data analysis in community and landscape ecology. Pudoc Wageningen, p. 91-173

ter Braak, C. J. F. (1987b). CANOCO - a FORTRAN program for canonical community ordination by (partial) (detrended) (canonical) correspondence analysis and redundancy analysis (version 2.1). TNO, Wageningen

Manuscript first received: March 26, 1990

Revised version accepted: July 5, 1990 